\title{
A chemical and multivariate statistical approach to assess the spatial variability of soil quality for environment around the Tamabil coal stockpile, Sylhet
}

\author{
M. Farhad Howladar ${ }^{1 *}$, Md. Mustafizur Rahman ${ }^{1}$, Fakir Saleh Abdullah Anas ${ }^{1}$ and Fazal Md. Mohi Shine ${ }^{2}$
}

\begin{abstract}
Background: The aim of this study is to evaluate the quality of soil for environment in terms of the spatial distribution patterns of some selected elements such as $\mathrm{pH}$, total nitrogen $\left(\mathrm{N}_{2}\right)$, sulfur $(\mathrm{S})$, potassium $(\mathrm{K})$, phosphorus $(\mathrm{P})$, iron (Fe), and arsenic (As) in 42 surface and sub-surface soil samples. These samples were collected from different locations around the coal stockpiles of Tamabil, Sylhet. However, primarily the collected soil samples were tested in the laboratory. Consequently, these data were computed and justified under multivariate statistical approaches for example correlation matrix, principal component, and factor analysis.
\end{abstract}

Results: The examined soils showed a high variability in the element concentrations especially in the case of $\mathrm{pH}$ and sulfur. The principal component and factor analyses reflected that the total variance of surface soil is $79.89 \%$ whereas it is $80.99 \%$ for subsurface soil. This result suggests that the soil-coal interaction with anthropogenic impact is the dominant factors for affecting the soil quality. The correlation matrix of surface and subsurface soil, from where it is cleared that there is no parameters are neither strongly positively correlated nor negatively correlated with each other. It implies that the heterogeneous source of different components of soil and possible ionic variability may be contributed from multiple anthropogenic sources.

Conclusions: At the end based on the present analysis, the soil quality of the study area is becoming acidic. If precautions are not taken immediately, the people and other living organisms will face difficulties. Therefore, a particular area should be used for coal stocking place, and there should be a proper barrier so that coal can't mixed with the surrounding soil and water of the environment. Consequently, it will be helpful to prevent the degradation of the environment.

Keywords: Tamabil coal stockpiles, Soil chemistry, Multivariate approach, Environment

\section{Background}

Coal stockpiles can be a dangerous threat to the surrounding environment and ecosystem. It undesirably affects water and soil quality, which in turn may adversely affect plants, animals, and humans (Carlson 1990). Coal stockpiles release fine dust in dry condition and during

\footnotetext{
*Correspondence: farhadpme@gmail.com; farhad-pme@sust.edu; dmfh75@yahoo.com

${ }^{1}$ Department of Petroleum \& Mining Engineering, Shahjalal University of Science and Technology, Sylhet 3114, Bangladesh

Full list of author information is available at the end of the article
}

rainy season chemical parameters of coal mixed with soil and water through the leaching process. Firstly, the wind blows over uncovered coal stockpiles results in fugitive coal dust emissions that are a source of air pollutants (The Conversation 2017). Secondly, coal stockpiles emit volatile gases that can also lead to the formation of air pollutants (The Conversation 2017). Indian coal is imported in Bangladesh through the Tamabil (Sylhet) border and stockpiled in open spaces of the adjacent to the border area which contains high sulfur. Sylhet is the most rainfall area of Bangladesh because it is a hilly region and near 
to Cheripunjo of India. Sulfur may form sulfuric-acid through the reaction process with water. Accordingly, the risk of acid formation is very high in this region as water is very much available here. Sylhet is also an agricultural region and acid formation may alter the chemical properties of the soil. So, it is very much important to execute a research on this area to evaluate the chemical properties of soil so that a precise idea about the surrounding area of the coal stockpiles can be obtained. In order to understand the soil quality. the multivariate statistical analysis has been applied. Recently, a considerable number of researchers have shown an increased interest in the use of multivariate statistical analysis and geostatistical techniques to achieve a sustainable exploitation of water and soil resources (Narany et al. 2014; Howladar et al. 2014; Howladar 2015; Howladar and Hossain 2015; Belkhiri and Narany 2015; Howladar and Rahman 2016). Therefore, the main aims of this study are to examine the chemical parameters of the soil of the study area, applying various methods to explain the soil quality and its possible contaminants. Finally, discussed the link between potential causes and consequences of environmental problems around the study area.

\section{Location of study area and stratigraphy}

\section{Location of study area}

The study areas is situated in and around the coal and lime storage area under 3 no. east Jaflong union of
Gowainghat Upazila (Fig. 1) and also some area are situated in Jaintiapur upazilla, Sylhet. The study area covers the village of Nilguri, Tamabil, Adorsho gram, Gujchho, and adjacent areas of these villages. The latitude and longitude of the areas are $\mathrm{N} 25^{\circ} 09^{\prime} 56.3^{\prime \prime}$ to $\mathrm{N} 25^{\circ} 10^{\prime} 23.3^{\prime \prime}$ and E092 $06^{\prime} 11.2^{\prime \prime}$ to E092 $05^{\prime} 29.6^{\prime \prime}$.

\section{Stratigraphy}

Tamabil has been differentiated into eight stratigraphic formations such as Alluvium, Dihing, Dupi Tila, Girujan clay, Tipam sandstone, Renji, Kopili shale, and Sylhet limestone. Sylhet limestone formation has been found as the oldest unit in the formation sequence which was formed in Eocene age. The thickness of this formation is about $25 \mathrm{~m}$. It gives a clear message that formation lithology is completely composed of sedimentary rock. From the stratigraphic succession of the study area, it has been found that Surma group [a stratigraphic unit (Reimann 1993), named after Surma valley by Evans (1932)] has the highest thickness of $1309 \mathrm{~m}$, which was formed in the Miocene age. The lithology has been dominated by fine to very fine grain sandstone with bullish gray laminated shale (Hiller and Elahi 1988).

\section{Method of analysis}

Sample collection and data analysis

Samples were collected during the rainy season in the year 2014. Total 42 samples were randomly collected

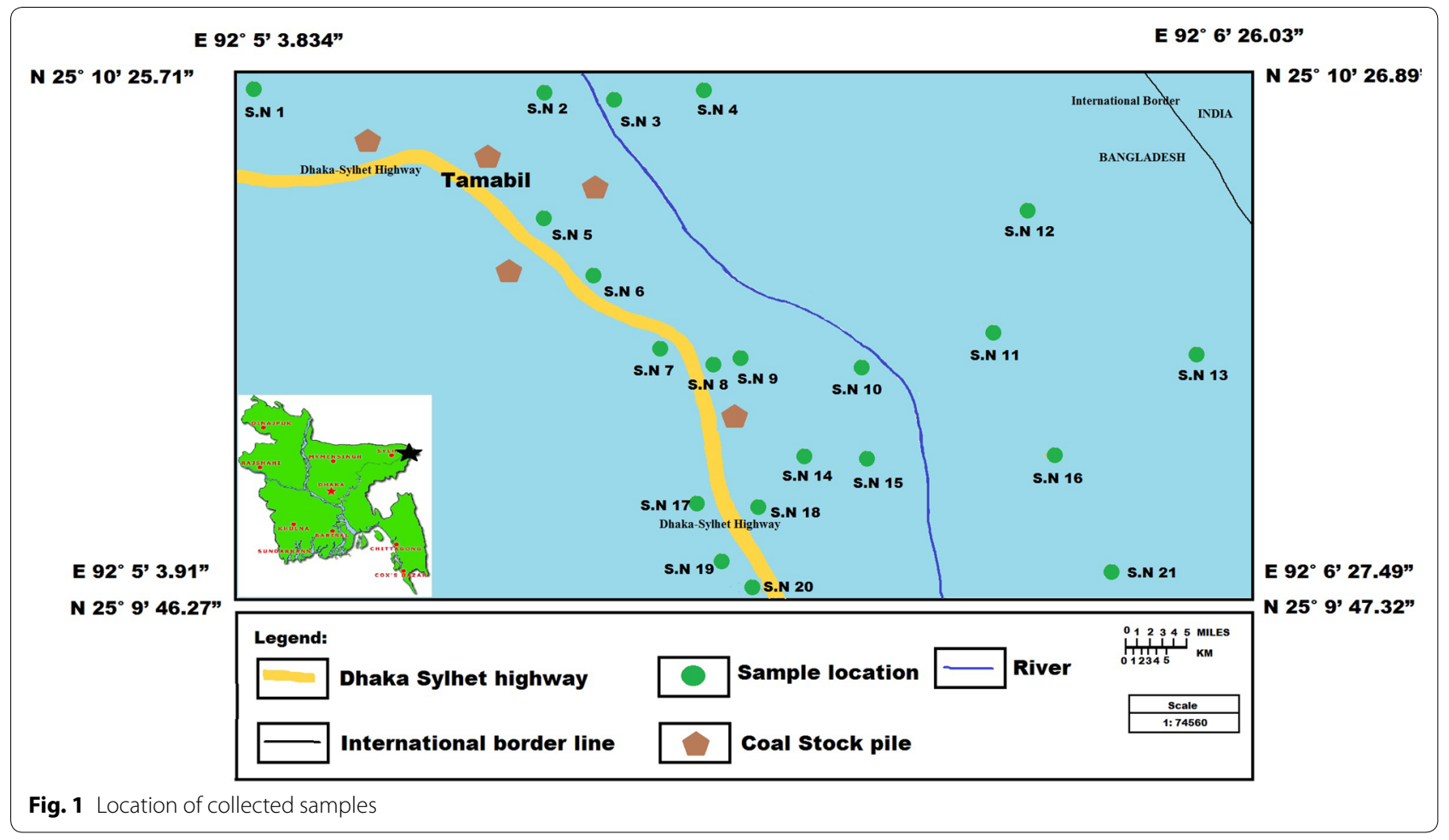


from the study area among them 21 samples were collected from the surface (around $0.5 \mathrm{ft}$ depth) and $21 \mathrm{sam}$ ples were collected from the sub-surface. Sub-surface samples were collected from a $1.5 \mathrm{ft}$ depth of the surface. Locations of sampling points were determined using a Global Positioning System and were used for plotting these points on a map (Fig. 1). About $2 \mathrm{~kg}$ of soil was collected for each site. The collected soil samples were placed in polyethylene bags and transported on the day of sampling to the laboratory. During sample collection, transport, storage, and treatment procedures were followed to minimize the possibility of contamination. In the laboratory, the important chemical parameters were determined for each sample.

Eight chemical properties of each sample, including $\mathrm{pH}$, organic matter $(\mathrm{OM})$, potassium $(\mathrm{K})$, sulfur $(\mathrm{S})$, nitrogen $(\mathrm{N})$, phosphorus $(\mathrm{P})$, iron $(\mathrm{Fe})$, and arsenic (As) were determined. The $\mathrm{pH}$ of the soil sample was determined by using a digital $\mathrm{pH}$ meter. Organic matter $(\mathrm{OM})$ was determined following potassium chromate method for determination of soil organic matter (NY/T 1121.6 2006; Rahman et al. 2017). Potassium (K) of the soil samples was determined by Potassium Strip Test (Rahman et al. 2017). Phosphorus (P) was determined by the modified Olsen method (neutral + calcareous soil) (Olsen 1954), Total nitrogen $(\mathrm{N})$ by the Kjeldahl method explained by Subbiah and Asija (1956), sulfur (S) was determined by using ion chromatography, iron ( $\mathrm{Fe}$ ) was determined by spectrophotometer and arsenic (As) was determined by Hach EZ Arsenic test kit (USA).

\section{Statistical approaching (correlation matrix, PCA and box plot analysis)}

A correlation matrix is used in this research for identifying the correlations between chemical parameters. The correlation matrix is done by using Statistica software (Version 08). Moreover, PCA is the most frequently applied tool for analyzing the interrelationship among different sets of soil sample data to extract the most significant factors and to reduce the data with minimum loss of information (Mustapha and Aris 2012; Schaefer and Einax 2010; Belkhiri and Narany 2015). In this research work, PCA is applied to soil sample data for determining the principal factors corresponding to the different sources of variation in the data and for identifying the spatial source of contamination in the study area (Belkhiri and Narany 2015). PCA is done with the help of SPSS software (Version 22).

A box and whiskers analysis is a compatible way for determining the spatial variability of the data. Moreover, a box and whiskers analysis helps to determine the spatial variability of the parameters. Microsoft Excel is used in this research work for executing boxplot analysis.

\section{Result and discussion}

Analyzed chemical characteristics and the quality of soil

The values of every chemical parameters and $\mathrm{pH}$ of soil are divided into seven classes such as very low, low, medium, optimum, high, very high and critical limit (Table 1). Here, the optimum limit of $\mathrm{pH}$ for agricultural purposes is 6.5. Again, the optimum limit for total nitrogen, OM, P, K, S, and Fe are 0.271-0.36, 2.7-3.4, 15.76$21.0,0.271-0.36,22.51-30.0$, and $9.1-12.0$ consecutively. The statistical table (Table 2) is showing the mean and standard deviation of different chemical parameters of 21 surface and 21 sub-surface samples. In this study, high deviation values are considered because it indicates the variability of the samples. Low Standard deviation indicates uniformity in the sample's chemical parameter. It shows (Table 2) that the range of sulfur has the highest deviation for both surface and subsurface samples. For surface samples, standard deviation of sulfur is 42.66 and for sub-surface samples, standard deviation of sulfur is 45.84. From Table 2, it has been observed that the level of $\mathrm{pH}$, organic matter, phosphorus, sulfur, and iron in surface soil samples are higher than that of sub-surface soil samples. But, the intensity of total nitrogen and $\mathrm{K}$ of subsurface samples is higher than the intensity of the surface

Table 1 Recommended soil chemical test values for upland crops interpretation. Source Regional Laboratory, Soil Resource Development Institute, Bangladesh (2014)

\begin{tabular}{|c|c|c|c|c|c|c|c|}
\hline Chemical parameters & Very low & Low & Medium & Optimum & High & Very high & Critical limit \\
\hline $\mathrm{pH}$ & $<4.5$ & $<5.5$ & $5.5-6$ & 6.5 & $>7.5$ & $>8$ & 5 \\
\hline Total nitrogen (\%) & $\leq 0.09$ & $0.091-0.18$ & $0.181-0.27$ & $0.271-0.36$ & $0.361-0.45$ & $>0.45$ & 0.12 \\
\hline OM & $<1$ & $1.0-1.7$ & $1.8-2.6$ & $2.7-3.4$ & $3.5-5.5$ & $>5.5$ & 1.2 \\
\hline$P_{,}(\mu g / g)$ & $\leq 5.25$ & $5.251-10.5$ & $10.51-15.75$ & $15.76-21.0$ & $21.1-26.25$ & $>26.25$ & 7.0 \\
\hline K, (meq/100 g) & $\leq 0.09$ & $0.091-0.18$ & $0.181-0.27$ & $0.271-0.36$ & $0.361-0.45$ & $>0.45$ & 0.12 \\
\hline $\mathrm{S},(\mu \mathrm{g} / \mathrm{g})$ & $\leq 7.5$ & $7.51-15.0$ & $15.1-22.5$ & $22.51-30.0$ & $30.1-37.5$ & $>37.5$ & 10.00 \\
\hline $\mathrm{Fe},(\mu \mathrm{g} / \mathrm{g})$ & $\leq 3$ & $3.1-6.0$ & $6.1-9.0$ & $9.1-12.0$ & $12.1-15.0$ & $>15.0$ & 4.00 \\
\hline
\end{tabular}


Table 2 Mean and standard deviation of soil samples

\begin{tabular}{lcc}
\hline Chemical parameters & $\begin{array}{l}\text { Mean } \pm \text { standard } \\
\text { deviation } \\
\text { Range: layer one } \\
\text { (surface, around } \mathbf{0 . 5} \\
\mathbf{f t})\end{array}$ & $\begin{array}{l}\text { Mean } \pm \text { standard } \\
\text { deviation } \\
\text { Range: layer 2 } \\
\text { (1.5 ft, sub- } \\
\text { surface) }\end{array}$ \\
\hline $\mathrm{pH}$ & $4.93 \pm 0.98$ & $4.91 \pm 0.94$ \\
Total nitrogen & $0.28 \pm 0.14$ & $0.30 \pm 0.19$ \\
OM & $3.57 \pm 2.01$ & $3.23 \pm 1.88$ \\
K & $0.31 \pm 0.27$ & $0.46 \pm 0.29$ \\
P & $6.48 \pm 2.50$ & $5.5 \pm 1.20$ \\
S & $56.49 \pm 42.66$ & $45.02 \pm 15.84$ \\
Fe & $10.49 \pm 5.24$ & $10.06 \pm 5.55$ \\
As & $0.03 \pm 0.05$ & $0.03 \pm 0.06$ \\
\hline
\end{tabular}

samples. Comparing with the upland crops interpretation of soil test values, it seems that the average value of total nitrogen and Fe is in optimum level both for surface soil samples (around $0.5 \mathrm{ft}$ ) and for samples $1.5 \mathrm{ft}$ below the surface. But for $\mathrm{K}$ average values of surface samples are in optimum level but samples below $1.5 \mathrm{ft}$ have very high $\mathrm{K}$ (Table 2). Therefore, comparing with the recommended optimum standard (Table 1) of chemical nutrients, it has been found that total nitrogen, $\mathrm{K}$, and $\mathrm{Fe}$ are within the optimum range for both types of soil samples but $\mathrm{S}$ is very high for both types of soil samples. Moreover, $\mathrm{S}$ is the main reason for low $\mathrm{pH}$ of the study area. This is a clear indication of soil pollution which is associated with the coal stockpiles activities in the area.

On the other hand, the mean value of $\mathrm{P}$ is low both for surface and subsurface samples. But the most important fact is the amount of S for both surface and subsurface samples are very high. This is the direct impact of coal stockpiles. As sulfuric acid is being generated, the $\mathrm{pH}$ of both surface and sub-surface samples is low in the area. Average $\mathrm{pH}$ of surface samples is 4.91 and the average $\mathrm{pH}$ of subsurface samples is 4.93. It reflects that surface soil is relatively acidic in nature and that because of the coal stockpiles. The imported coal has a high amount of sulfur and because of that coal stockpiles surrounding soil is becoming acidic and ultimately threatening the environment.

\section{Correlation matrix, PCA and box plot analysis for understanding the spatial variability of soil quality}

For assessing the dependence on chemical parameters correlation matrix is in this research work. The categorization of principal components is done in this research as "strong", "moderate" and "weak", corresponding to absolute loading values of $>0.75,0.75-0.50$ and $0.50-0.30$, respectively (Liu et al. 2003; Rahman et al. 2017). Table 3 is showing the correlation matrix coefficient of surface soil samples while Table 4 is entailing about the correlation matrix coefficient of subsurface soil samples. In the case of surface soil samples, significant positive correlation values have been found for OM: P and S: As (Table 3). Moreover, high negative correlation values have been found for $\mathrm{pH}$ : $\mathrm{S}$ (Table 3). On the contrary, in the case of subsurface soil samples, significant positive correlation values have been found for K: As (Table 4). Moreover, high negative correlation values have been found for total nitrogen: P, OM: K, K: P and P: As (Table 4).

An eigenvalue gives a measure of the significance of the factor and factors with the highest eigenvalues are the most significant (Howladar et al. 2017; Rahman et al. 2017). The eigenvalues of 1.0 or greater are considered significant (Howladar et al. 2017; Rahman et al. 2017). From Table 5 it is obvious that for surface soil samples Factor 1, Factor 2, Factor 3 and Factor 4 have the eigenvalues of 2.30, 1.69, 1.27 and 1.13 respectively. However, from Table 6 it is seen that for sub-surface soil samples Factor 1, Factor 2, Factor 3 and Factor 4 have the eigenvalues of $2.69,1.66,1.12$ and 1.00 respectively. So, the eigenvalue of Factor 1 is more significant than other factors for both surface and subsurface soil samples. However, the eigenvalue of Factor 2 is also pretty high, which because of the high value of sulfur (S) found after

Table 3 Correlation matrix for surface soil samples

\begin{tabular}{|c|c|c|c|c|c|c|c|c|}
\hline Variables & $\mathrm{pH}$ & Total $\mathrm{N}_{2}$ & OM & $\mathrm{K}$ & $P$ & $S$ & $\mathrm{Fe}$ & As \\
\hline $\mathrm{pH}$ & 1.00 & & & & & & & \\
\hline Total nitrogen & 0.04 & 1.00 & & & & & & \\
\hline $\mathrm{OM}$ & -0.16 & -0.16 & 1.00 & & & & & \\
\hline K & 0.280 & -0.21 & -0.09 & 1.00 & & & & \\
\hline P & -0.22 & 0.12 & 0.47 & 0.25 & 1.00 & & & \\
\hline S & -0.41 & -0.13 & -0.17 & -0.16 & -0.18 & 1.00 & & \\
\hline $\mathrm{Fe}$ & -0.056 & -0.02 & 0.03 & 0.04 & 0.32 & 0.24 & 1.00 & \\
\hline As & -0.299 & -0.03 & -0.32 & -0.29 & -0.15 & 0.71 & 0.41 & 1.00 \\
\hline
\end{tabular}

** Italic values indicate the significant correlation between the various chemical parameters 
Table 4 The correlation matrix for sub-surface soil samples

\begin{tabular}{|c|c|c|c|c|c|c|c|c|}
\hline Variables & $\mathrm{pH}$ & Total nitrogen & OM & $\mathbf{K}$ & $\mathbf{P}$ & $S$ & $\mathrm{Fe}$ & As \\
\hline $\mathrm{pH}$ & 1.00 & & & & & & & \\
\hline Total nitrogen & 0.02 & 1.00 & & & & & & \\
\hline $\mathrm{OM}$ & -0.13 & -0.19 & 1.00 & & & & & \\
\hline K & -0.03 & -0.09 & -0.61 & 1.00 & & & & \\
\hline P & -0.02 & -0.47 & 0.33 & -0.48 & 1.00 & & & \\
\hline S & 0.05 & 0.13 & -0.07 & 0.19 & -0.33 & 1.00 & & \\
\hline $\mathrm{Fe}$ & 0.14 & -0.42 & 0.004 & 0.36 & 0.006 & 0.008 & 1.00 & \\
\hline As & -0.19 & 0.08 & -0.39 & 0.54 & -0.48 & 0.42 & 0.35 & 1.00 \\
\hline
\end{tabular}

** Italic values indicate the significant correlation between the various chemical parameters

Table 5 Total variance explained for surface samples

\begin{tabular}{lllll}
\hline Factor & Eigen values & $\begin{array}{l}\text { Total } \\
\text { variance } \\
\text { (\%) }\end{array}$ & $\begin{array}{l}\text { Cumulative } \\
\text { Eigen values }\end{array}$ & $\begin{array}{l}\text { Cumulative } \\
\text { variance (\%) }\end{array}$ \\
\hline 1 & 2.30 & 21.14 & 2.30 & 21.14 \\
2 & 1.69 & 28.81 & 3.99 & 49.95 \\
3 & 1.27 & 15.83 & 5.26 & 65.77 \\
4 & 1.13 & 14.11 & 6.39 & 79.89 \\
\hline
\end{tabular}

Table 6 Total variance explained for subsurface samples

\begin{tabular}{lllll}
\hline Factor & Eigen values & $\begin{array}{l}\text { Total } \\
\text { variance } \\
\text { (\%) }\end{array}$ & $\begin{array}{l}\text { Cumulative } \\
\text { Eigen values }\end{array}$ & $\begin{array}{l}\text { Cumulative } \\
\text { variance (\%) }\end{array}$ \\
\hline 1 & 2.69 & 33.75 & 2.69 & 33.75 \\
2 & 1.66 & 20.75 & 4.36 & 54.49 \\
3 & 1.12 & 13.99 & 5.48 & 68.49 \\
4 & 1.00 & 12.50 & 6.48 & 80.99 \\
\hline
\end{tabular}

chemical analysis of soil samples (Table 2). Therefore, the Tables 5 and 6 it has been found that four factors describe almost $80 \%$ that indicates they define most of the variability so these factors are decent and so these factors can be used as the replacement of other factors. For surface soil samples, first-factor loading explained $21.14 \%$ of the total variance (Table 5) and second-factor loading explained $28.81 \%$ of the total variance. The results of first-factor loading provide evidence of both natural and the anthropogenic factor impact in the study area (Belkhiri and Narany 2015). Here, for surface soil samples, anthropogenic impact is more than the natural impact. However, for subsurface soil samples comparatively transposed scenario is observed, where First-factor loading explained $33.75 \%$ of the total variance and Second-factor loading explained $20.75 \%$ of the total variance.

Tables 7 (surface soil samples) and 8 (sub-surface soil samples) are presenting the loadings of four factors (loading is obtained by unrotated factor matrix). For surface
Table 7 Factor loadings obtained with unroasted factor matrix (surface samples)

\begin{tabular}{lcccc}
\hline Parameters & Factor $\mathbf{1}$ & Factor $\mathbf{2}$ & Factor $\mathbf{3}$ & Factor 4 \\
\hline $\mathrm{pH}$ & 0.51 & -0.47 & 0.38 & -0.23 \\
Total nitrogen & 0.04 & -0.08 & -0.44 & -0.84 \\
$\mathrm{OM}$ & 0.31 & 0.71 & -0.29 & 0.32 \\
$\mathrm{~K}$ & 0.42 & 0.07 & 0.75 & 0.02 \\
$\mathrm{P}$ & 0.24 & 0.85 & 0.07 & -0.26 \\
$\mathrm{~S}$ & -0.86 & 0.04 & 0.12 & 0.17 \\
$\mathrm{Fe}$ & -0.38 & 0.48 & 0.47 & -0.39 \\
As & -0.91 & -0.01 & 0.15 & -0.11 \\
\hline Italic values represent that level of significance among different parameters
\end{tabular}

soil samples (Table 7), it can be said that Factor 2 has more positive dominance than other factors. But, Factor 1 has more negative factor scores. So, it can be said that surface soil samples are degraded because of the anthropogenic causes. However, for subsurface soil samples (Table 8), Factor 1 has more dominance than other factors (Factor 1 has both high and low factor scores). However, Factor 2 also has one high positive and negative factor scores, so it can be revealed that subsurface soil samples are also degraded a bit because of the anthropogenic causes but degradation is relatively less than the surface soil samples.

Therefore, the results of Factor analysis satisfy the experimental value of laboratory analysis of the soil samples as well as give a strong sign about the tainted chemical parameters. The factor analysis result shows a clear indication of anthropogenic influence for both surface and subsurface soil samples but surface soil samples of the study area are more deviated than the subsurface samples that have been supported by similar scientific results done by Belkhiri and Narany (2015) and Rahman et al. (2017).

Figures 2 and 3 are showing the relationship between different factors. From the figures, three pairs of 
Table 8 Factor loadings obtained with unroasted factor matrix (sub-surface samples)

\begin{tabular}{lcccc}
\hline Parameters & Factor $\mathbf{1}$ & Factor $\mathbf{2}$ & Factor $\mathbf{3}$ & Factor $\mathbf{4}$ \\
\hline $\mathrm{pH}$ & 0.01 & 0.06 & 0.88 & -0.44 \\
Total nitrogen & -0.24 & -0.85 & 0.09 & 0.003 \\
$\mathrm{OM}$ & 0.67 & 0.05 & -0.41 & -0.45 \\
$\mathrm{~K}$ & -0.81 & 0.31 & 0.08 & 0.26 \\
$\mathrm{P}$ & 0.75 & 0.37 & -0.01 & 0.08 \\
$\mathrm{~S}$ & -0.48 & -0.16 & -0.24 & -0.69 \\
$\mathrm{Fe}$ & -0.28 & 0.80 & 0.04 & -0.20 \\
As & -0.81 & 0.15 & -0.32 & -0.07 \\
\hline
\end{tabular}

Italic values represent that level of significance among different parameters

chemical parameters are identified and they are strongly correlated with each other. So, in the contamination of surface soils, these three pairs are involved and these figures also show that factor 2 dominance over factor 1 and factor 3 . From the figure, it is also revealed that for surface soil samples, sulfur is the common chemical parameter so the main reason of soil degradation is sulfur and the source of sulfur in the study area is imported coal. In case of, subsurface soil samples sulfur is also high but not as much as surface soil samples, which is also because of the coal and through leaching process subsurface soil samples are affected. So, it is clear from all analysis that contamination of soil samples is due to anthropogenic reasons.

The box signifies the values between the first and third quartile. The whiskers represent the distances between the lowest observation to the first quartile and the fourth quartile to the highest observation (Interworks 2017). Each quartile has a specific numeric value, determined from the data set (Interworks 2017). A figure of box and whiskers is shown below (Fig. 4).

From the box plot of different chemical parameters indicates that sulfur has a wide spatial variation of its concentration. That means samples of different locations possess a different level of concentrations. This box plot also tells that spatial variation of sulfur varies much in the upper quartile portion (Fig. 5). But for Total N, OM, K, P, Fe, and As spatial variation in concentration is not so significant has been supported by similar methodical results done by Mzuku et al. (2005).

\section{Quality of soil and environment}

Soil is an important natural resource supports plant growth and other human needs. But, the presence of pollutants can affect soil quality and impair its life-sustaining capacity. It is therefore important to identify the soil characteristics responsible for changes in soil quality, which may eventually be considered as soil quality indicators

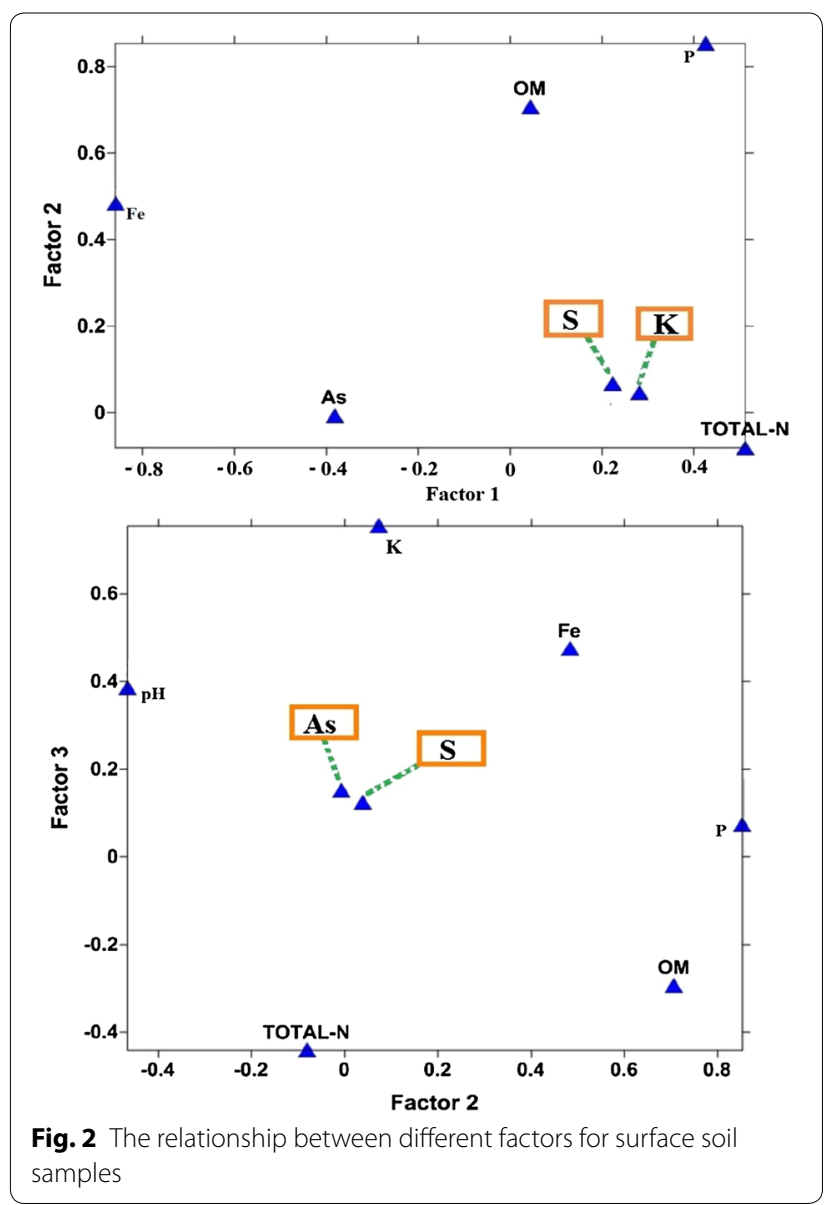

for assessing environmental sustainability (Masto et al. 2007, 2008). From the chemical analysis of the surface and sub-surface soil, it has been found that $\mathrm{pH}$ and sulfur are mostly degraded from their natural value. It is a staid problem for the agricultural land of the surrounding area. The desired $\mathrm{pH}$ for good vegetation ranges from 5.5 to 6.8 . The $\mathrm{pH}$ is a good measure of acidity and alkalinity of soil water suspension and it provides a good identification of soil chemical nature (Sharma 2008). The intensity level of $\mathrm{pH}$ and sulfur is shown in Figs. 5, 6, 7, 8. From the intensity Contour of pH for surface soil shown in Fig. 6, it is clear that near the coal stockpile area $\mathrm{pH}$ is very low. This is because of the quality of the coal stored on the site. The same type of condition is also encountered for sub-surface samples, which is shown in Fig. 7. The value of $\mathrm{pH}$ in the soil was below the standard limits. This may be due to oxidation of pyrite which is generally present in coal controls the lowering of $\mathrm{pH}$. The $\mathrm{pH}$ affects nutrient accessibility by altering the nutrient form. For example, nitrogen (affected by $\mathrm{pH}$ ) have different leaching capabilities; other nutrients may become adsorbed or desorbed, precipitated, mineralized, or immobilized at different $\mathrm{pH}$ values (Cornell University nutrient management 2010). 


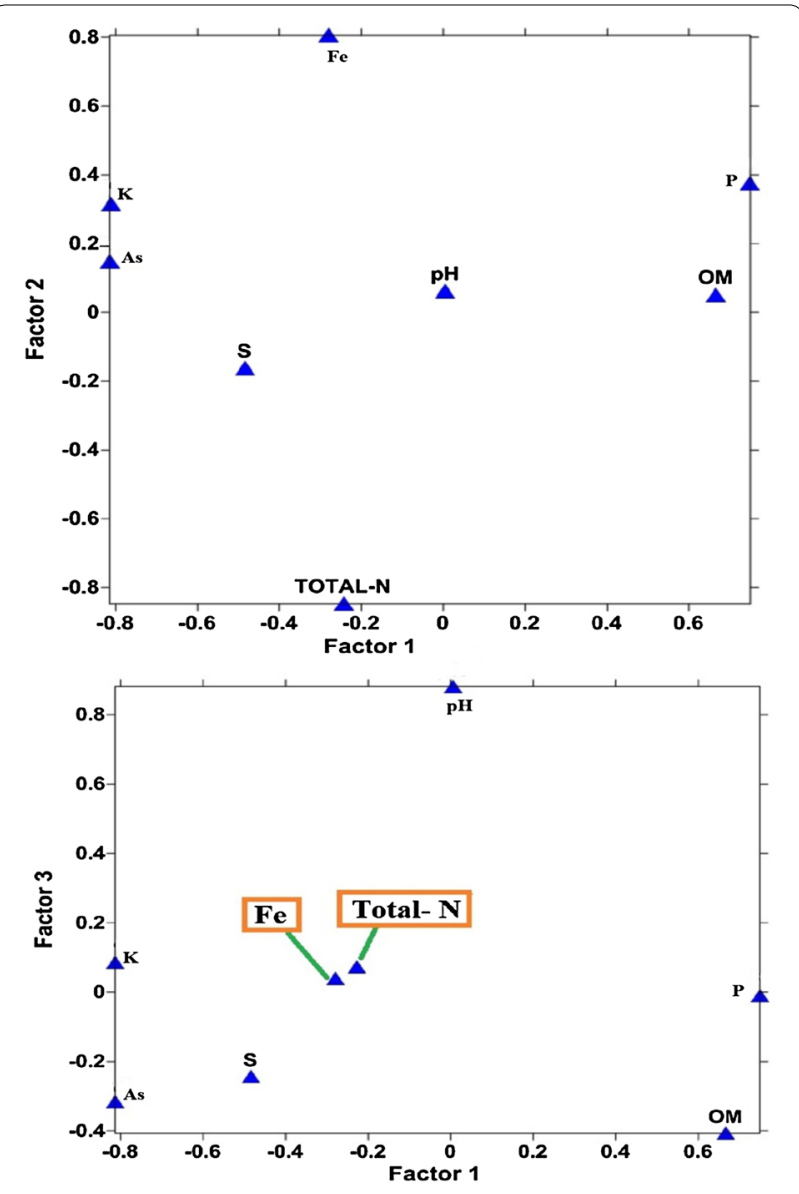

Fig. 3 The relationship between different factors for sub-surface soil samples

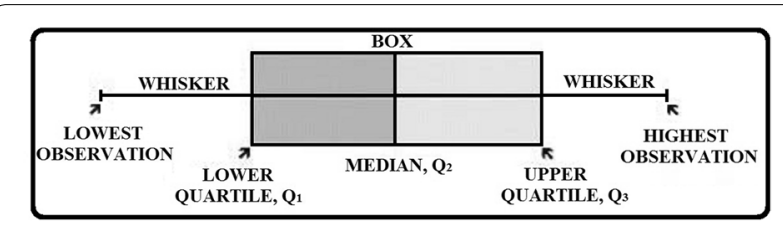

Fig. 4 The box and whiskers (Modified after Interworks 2017)

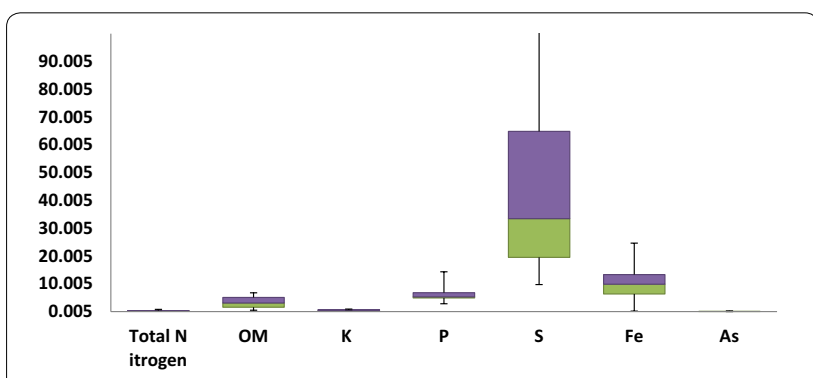

Fig. 5 The box-pot of all chemical parameters
Many nutrients are more available in slightly acid soils: $\mathrm{P}$ is most available at a neutral pH (about 6.5) (Cornell University nutrient management 2010). The $\mathrm{pH}$ is also important in nitrogen transformations, such as mineralization, nitrification, and nitrogen fixation, as the bacteria involved are $\mathrm{pH}$-sensitive (Cornell University nutrient management 2010).

From the intensity contour map of sulfur for surface soil samples (Fig. 8), the amount of sulfur near the coal yard is very high. And the amount of sulfur is getting lesser as the samples are collected from far away from the coal yard. The soil became contaminated with sulfur by the leaching process. The similar situation is also seen for sub-surface soil samples. The intensity contour map of sulfur (Fig. 9) is showing that the amount of sulfur in sub-surface samples near coal yard is low but the amount is high for the samples which are collected from far away from the coal yard. The increase in the element was likely due to the leaching of the stored coal upon contact with water. However, based on the characteristics of stored coal (Hashan et al. 2013; Hashan et al. 2016) it appears that $S$ in soil might have originated from the coal and the rest might have originated from other anthropogenic sources. The $\mathrm{pH}$ of the soil-water system seems to be controlled by the ratio between ubiquitous $\mathrm{Ca}$ and $\mathrm{S}$ concentrations in coal ash (Querol et al. 2001; Howladar et al. 2018), although other minor alkalis or alkaline earth cations such as $\mathrm{Mg}$ may also contribute to the balance (Ward et al. 2009). The contribution of $\mathrm{Zn}, \mathrm{P}, \mathrm{N}, \mathrm{Fe}, \mathrm{OM}$ and other elements into the soil from stored coal is also possible and can degrade soil quality which is directly or indirectly linked with environmental pollution and human health in many ways (Zornoza et al. 2015).

\section{Conclusions}

Tamabil border area is a very attractive tourist spot and plays a major role in the tourism sector of Bangladesh. Nevertheless, unplanned coal stockpiles are polluting the surrounding soil. In addition, imported coals contain $0.4-0.6 \%$ of sulfur that is a great concern in the environmental perspective. From the analysis of soil samples, it has been identified that some vital chemical parameters are tainted. Moreover, there is a lot of spatial variability of soil samples. Especially, the quantity of sulfur is very high in the soil samples. From this research, it has also been identified that sulfur content is very high closed to the coal stockpile area. So it is that coal stockpile is one of the possible point source of degrading the quality of soil and also the environment of the surrounding the area. 


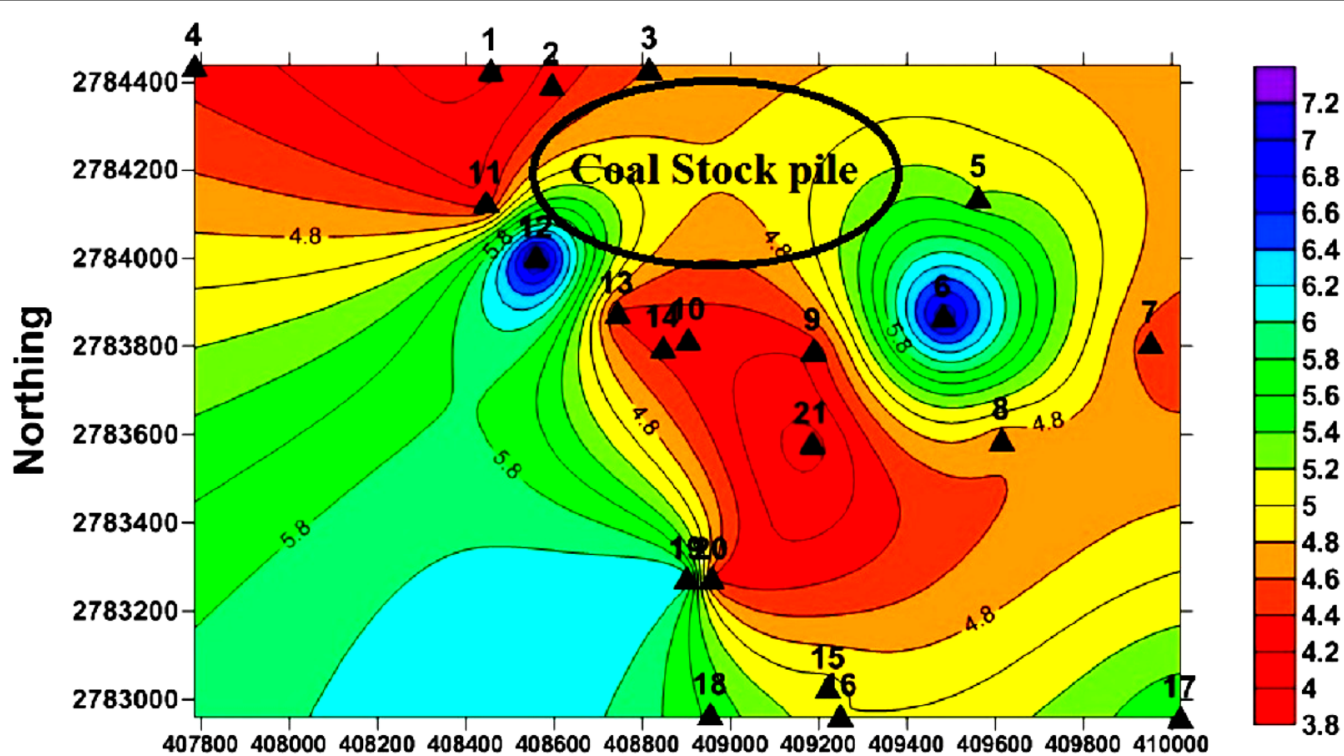

\section{Easting}

Fig. 6 The intensity of $\mathrm{pH}$ for surface soil samples

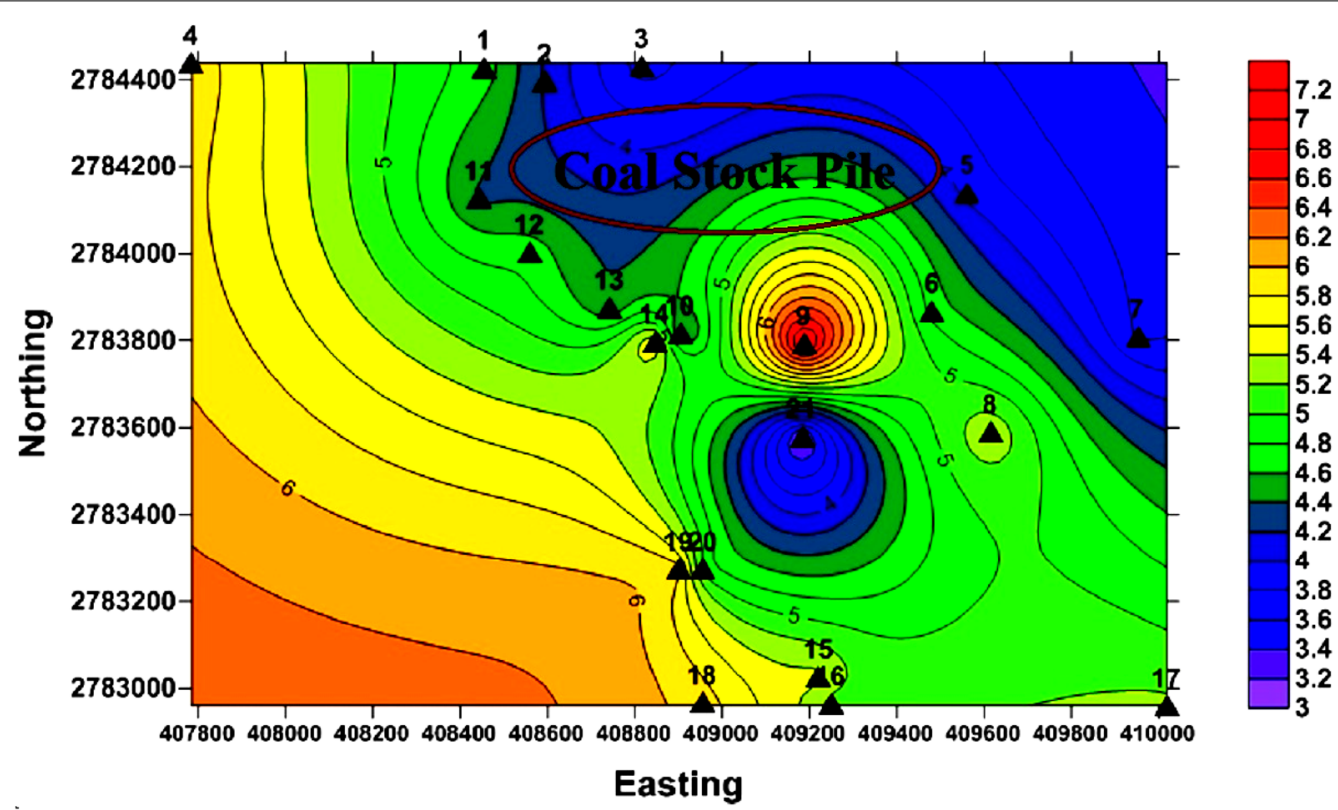

Fig. 7 The intensity of $\mathrm{pH}$ for sub-surface soil sample

In addition, the principal component analysis (PCA) confirms that the soil samples are tainted mostly because of the anthropogenic causes i.e. because of the coal stockpiles. Moreover, from box plot analysis it has been found that spatial variability of sulfur is very high than other chemical parameters. Again, the $\mathrm{pH}$ value of the surrounding area is also very low because of the high sulfur content. Mean $\mathrm{pH}$ value of the surface soil samples have been found 4.93 and for sub-surface soil samples, it is 4.91. The High sulfur content of coal is also degrading the amount of Phosphorus in the study area. As Phosphorus is a very important element of soil, especially when the aim is to produce agricultural products. This condition will become worse day by day. If this degradation continues, 

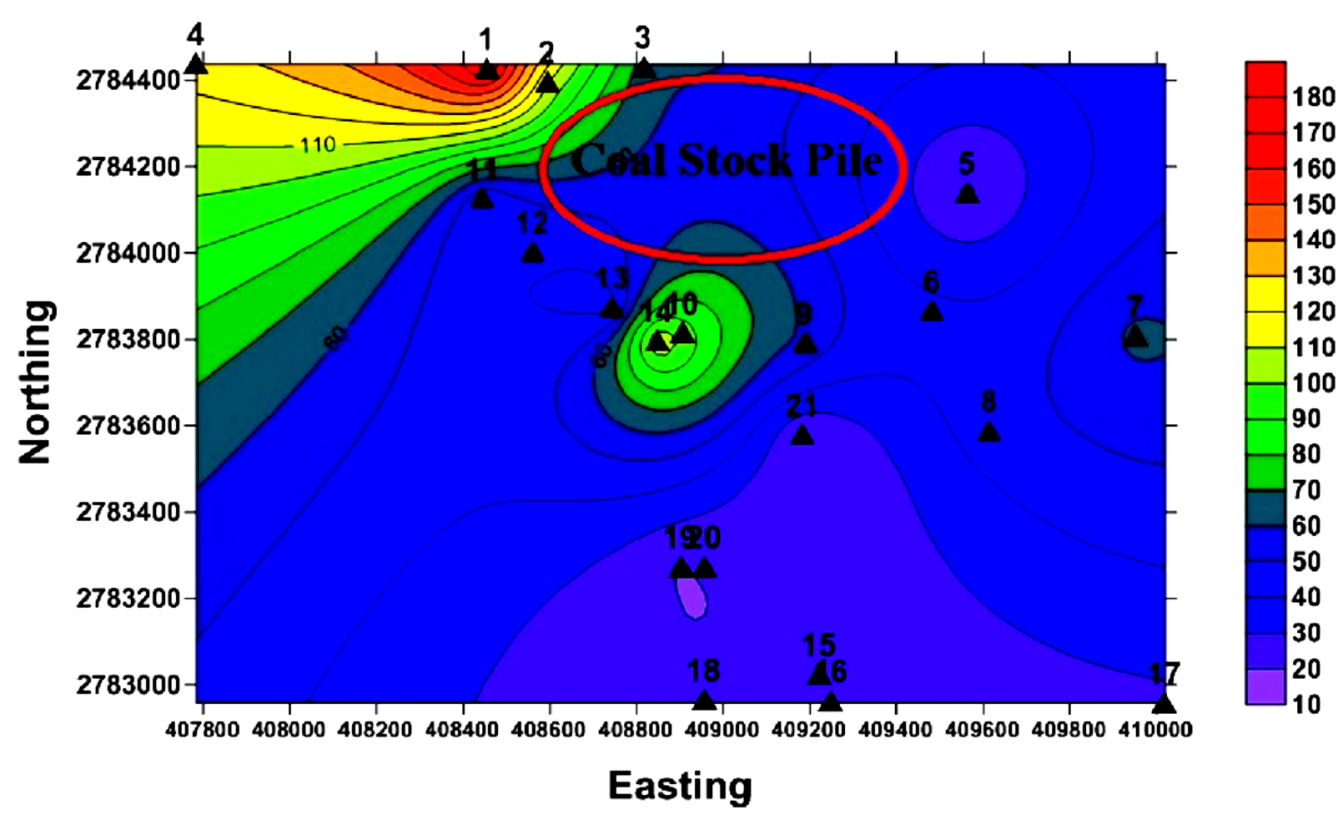

\section{Easting}

Fig. 8 The intensity of sulfur for surface soil sample

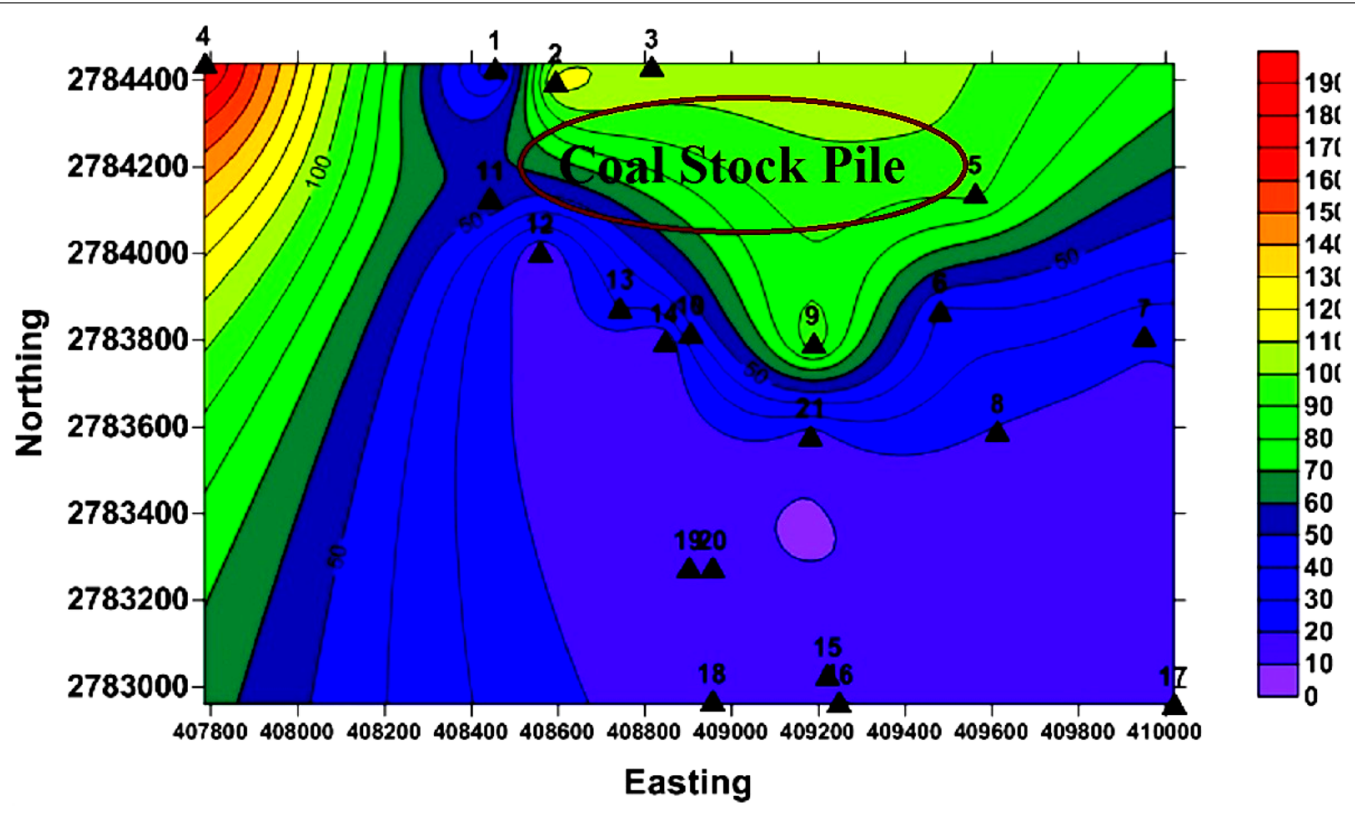

Fig. 9 The intensity of sulfur for sub-surface soil sample

there is a high risk of acid rain in that area, which would also be dangerous for the Sylhet region.

In conclusion, this study recommends that the regular monitoring of the imported coal quality with proper awareness program might have to be taken to protect the soil resources in the area.

\section{Authors' contributions}

MFH contributed to conception, design, and acquisition of data, data analysis and interpretation of data. MMR participated to acquisition of data, data analysis and interpretation of data as well as involved in drafting the primary manuscript. FSAA participated to acquisition of sample and data analysis. FMMS made a contribution to checking and revising the manuscript critically as well as maintaining the scientific merits with syntactic correctness for final submission of the manuscript. All authors read and approved the final manuscript. 


\section{Author details}

${ }^{1}$ Department of Petroleum \& Mining Engineering, Shahjalal University of Science and Technology, Sylhet 3114, Bangladesh. ${ }^{2}$ Department of Geology and Mining, University of Rajshahi, Rajshahi 6205, Bangladesh.

\section{Acknowledgements}

The authors would like to thank to the Ministry of Education, Bangladesh for the partial financial support to the successful completion of the research work, otherwise it was beyond our reach.

\section{Competing interests}

The authors declare that they have no competing interests.

\section{Availability of data and materials}

The data are presented in the main manuscript.

\section{Consent for publication}

Not applicable.

\section{Ethics approval and consent to participate}

Not applicable.

\section{Funding}

Not applicable.

\section{Publisher's Note}

Springer Nature remains neutral with regard to jurisdictional claims in published maps and institutional affiliations.

Received: 4 May 2018 Accepted: 1 August 2018

Published online: 09 August 2018

\section{References}

Belkhiri L, Narany TS (2015) (2015) Using multivariate statistical analysis, geostatistical techniques and structural equation modeling to identify spatia variability of groundwater quality. Water Resour Manage 29:2073-2089. https://doi.org/10.1007/s11269-015-0929-7

Carlson CA (1990) Subsurface leachate migration from a reject coal pile in south Carolin. Water Air Soil Pollut. https://doi.org/10.1007/bf00170748

Cornell university nutrient management (2010) https://nrcca.cals.cornell.edu/ nutrient/CA2/CA2_SoftChalk/CA2_print.html. Accessed 10 Nov 2017

Evans P (1932) Explanatory notes to accompany a table showing the Tertiary succession in Assam. Trans Mining Geol Inst India 27:155-260

Hashan M, Howladar MF, Jahan LN, Deb PK (2013) Ash content and its relevance with the coal grade and environment in Bangladesh. Int J Sci Eng Res 4(4):669-676

Hashan M, Jahan LN, Howladar MF (2016) Sulphur concentration in imported coal around the Tamabil area, Sylhet, Bangladesh. Int J Environ Monit Anal 4(1):27-30. https://doi.org/10.11648/j.ijema.20160401.15

Hiller K, Elahi M (1988) Structural growth and hydro-carbon entrapment in the surma basin. Cireum Pac Council Energy Miner Resour Earth Sci Ser 10:657-669

Howladar MF (2015) An analysis of soil quality for environment around the Barapukuria coal fired thermal power plant, Parbatipur, Dinajpur, Bangladesh. In: Earth resources, vol 3, pp 1-6. https://doi.org/10.12966/ ne.05.01.2015

Howladar MF, Hossain M (2015) Hydrogeochemistry and source of sulphate contamination of water environs around the coal storage Yard, Tamabil, Sylhet: an approach for environmental implications (unpublished research report)

Howladar MF, Rahman MM (2016) Characterization of underground tunnel water hydrochemical system and uses through multivariate statistical methods: a case study from Maddhapara Granite Mine, Dinajpur, Bangladesh. Environ Earth Sci 75:1501. https://doi.org/10.1007/s1266 5-016-6309-7
Howladar MF, Deb PK, Muzemder ATMSH, Ahmed M (2014) Evaluation of water resources around barapukuria coal mine industrial area, Dinajpur, Bangladesh. Appl Water Sci 4:203-222. https://doi.org/10.1007/s1320 1-014-0207-5

Howladar MF, Numanbakth MAA, Faruque MO (2017) An application of Water Quality Index (WQI) and multivariate statistics to evaluate the water quality around Maddhapara Granite Mining Industrial Area, Dinajpur, Bangladesh. Environ Syst Res 6:13. https://doi.org/10.1186/s40068-017-0090-9

Howladar MF, Hashan M, Rahman MM, Numanbakth MAA, Sohail MA, Shine FMM (2018) The quality of imported coal and its impact on environmental degradation. Environ Dev Sustaindoi. https://doi.org/10.1007/s1066 8-018-0197-9

Interworks (2017) Tableau essentials: chart types-box-and-whisker plot https ://interworks.com/blog/ccapitula/2014/12/09/tableau-essentials-chart -types-box-and-whisker-plot/. Accessed 30 May 2018

Liu WX, Li XD, Shen ZG, Wang DC, Wai OWH, Li SY (2003) Multivariate statistical study of heavy metal enrichment in sediments of the PearlRiver Estuary. Environ Pollut 121(3):377-388. https://doi.org/10.1016/S0269 -7491(02)00234-8

Masto RE, Chhonkar PK, Singh D, Patra AK (2007) Soil quality response to long-term nutrient and crop management on a semi-arid Inceptisol. Agr Ecosyst Environ 118:130-142. https://doi.org/10.1016/j.agee.2006.05.008

Masto RE, Chhonkar PK, Purakayastha TJ, Patra AK, Singh D (2008) Soil quality indices for evaluation of long-term land use and soil management practices in semi-arid sub-tropical India. Land Degrad Dev 19:516-529. https ://doi.org/10.1002/ldr.857

Mustapha A, Aris AZ (2012) Multivariate statistical analysis and environmental modeling of heavy metals pollution by industries. Pol J Environ Stud 21(5):1359-1367

Mzuku M, Khosla R et al (2005) Spatial variability of measured soil properties across site-specific management zones. Soil fertility \& plant nutrition. Soil Sci Soc Am J 69:1572-1579. https://doi.org/10.2136/sssaj2005.0062

Narany ST, Ramli MF et al (2014) Spatiotemporal variation of groundwater quality using integrated multivariate statistical and geostatistical approaches in Amol-Babol Plain, Iran. Environ Monit Assess $186: 5797-5815$

NY/T 1121.6-2006 (2006) Soil testing part 6: method for determination of soil organic matter. https://www.chinesestandard.net/List-PDF/ NY.aspx?PageNumber=11. Accessed 15 Nov 2017

Olsen SR (1954) Estimation of available phosphorus by extraction with sodium bicarbonate. U.S. Dept. Agriculture, Washington, p 939

Querol X, Alastuey A, Rodriguez S, Plana F, Ruiz CR, Cots N, Massague G, Puig O (2001) PM10 and PM2.5 source apportionment in the Barcelona metropolitan area, Catalonia, Spain. Atmos Environ 35:6407-6419

Rahman MM, Howladar MF, Faruque MO (2017) Assessment of soil quality for agricultural purposes around the Barapukuria coal mining industrial area, Bangladesh: insights from chemical and multivariate statistical analysis. Environ Syst Res 6:24. https://doi.org/10.1186/s40068-017-0101-x

Regional Soil research Development Institute, Bangladesh (2014) Soil chemical test values for upland crops interpretation (Unpublished report)

Reimann KU (1993) Geology of Bangladesh. Gebruder Borntrheger, Berlin, p $153 p$

Schaefer K, Einax J (2010) Analytical and chemometric characterization of the Cruces River in South Chile. Environ Sci Pollut Res 17(1):115-123

Sharma HP (2008) Study of the impact of municipal solid waste dumping on soil quality in Guwahati city. Pollut Res 27(2):327-330

Subbiah BV, Asija GL (1956) A rapid procedure for estimation of available nitrogen in soils. Curr Sci 25:259-260

The Conversation (2017) Even when it's sitting in storage, coal threatens human health. http://theconversation.com/even-when-its-sitting-in-stora ge-coal-threatens-human-health-80865, Accessed 25 Nov 2017

Ward CR, French D, Jankowski J et al (2009) Element mobility from fresh and long-stored acidic fly ashes associated with an Australian power station. Int J Coal Geol 80:224-236

Zornoza R, Acosta JA et al (2015) Identification of sensitive indicators to assess the interrelationship between soil quality, management practices and human health. Soil 1:173-185. https://doi.org/10.5194/soil-1-173-2015 